\title{
Cancer/Testis Antigen 1
}

National Cancer Institute

\section{Source}

National Cancer Institute. Cancer/Testis Antigen 1. NCI Thesaurus. Code C39286.

Cancer/testis antigen $1(180 \mathrm{aa}, \sim 18 \mathrm{kDa})$ is encoded by both the human CTAG1A gene and the human CTAG1B gene. This protein may be involved in both testis development and spermatogenesis. 